OPEN ACCESS

Edited by: Youji Wang

Shanghai Ocean University, China

Reviewed by:

Begum Yurdakok Dikmen, Ankara University, Turkey

David Bruce Conn,

Berry College, USA

*Correspondence:

Francesca Carella

francesca.carella@unina.it

Specialty section:

This article was submitted to

Aquatic Physiology,

a section of the journal

Frontiers in Physiology

Received: 22 July 2016

Accepted: 10 October 2016

Published: 01 November 2016

Citation:

Carella F, Villari G, Maio N and De Vico G (2016) Disease and Disorders of Freshwater Unionid Mussels: A Brief Overview of Recent

Studies. Front. Physiol. 7:489. doi: 10.3389/fphys.2016.00489

\section{Disease and Disorders of Freshwater Unionid Mussels: A Brief Overview of Recent Studies}

\author{
Francesca Carella *, Grazia Villari, Nicola Maio and Gionata De Vico \\ Department of Biology, University of Naples Federico II, Naples, Italy
}

The use of aquatic invertebrates in biomedical research and as environmental sentinels has dramatically grown in recent decades, with an increased need in understanding of comparative pathology. The Unionids freshwater mussels are a group of worldwide distributed bivalves residing small ditches and ponds, lakes, canals and rivers, often used as animal test in eco-toxicological studies. Once one of the most abundant bivalve molluscs in ancient rivers around the world, now many of them are declining in many countries and consequently are nearly extinct in many areas. The causes of this decline are not fully understood but alteration and degradation of the freshwater habitat seemed to play a central role. To date, link causality to the observed losses during episode of mussel die-offs has been more difficult to establish, and disease and pathogen presence have been scarcely considered. In this article we provide a brief overview of unionids freshwater mussel conservation status, also describing reported diseases and pathogens and illustrating a few relatively well-documented studies.

Keywords: Unionidae, freshwater mussels, animal disease, comparative pathology

\section{INTRODUCTION}

Invertebrate species represent a great percentage of animal diversity; however, they attract extremely minor research effort relative to vertebrates. Among them, non-marine molluscs (i.e., terrestrial and freshwater) are one of the most diverse and endangered animals with limited research specialists. In particular, freshwater mussels (Bivalvia: Unionoida) are a species-rich group of bivalves comprising about 900 nominal species in six families, including 300 species of Unionidae and 10 of Margaritiferidae, other than Hyriidae, Iridinidae, Mutelidae, Mycetopodidae with extant representatives ranging on all continents except Antarctica (Figure 1A). In particular, the characteristics that set the superfamily Unionoidea is the parental care of offspring until they are released as larvae, and the presence of parasitic larvae. Unionids adults are relatively sedentary, but in some species the larvae, the glochidia, are ectoparasite on fishes or amphibians, which provides a mechanism for dispersal. Concern about unionids populations has stimulated interest in the propagation of some species (Hanlon, 2003), but as for all cultured animals, there are numerous factors that affect the health of mussels reared in captivity (Jones et al., 2005). The potential for pathogens to kill or have sub-lethal effects on mussels in culture conditions has generally not been adequately evaluated. Here, we provide a brief overview of unionid freshwater bivalves considering animal conservation status; this is an attempt to describe the use of these organisms in ecotoxicological studies, also reporting diseases and pathogens of this group and illustrating a few relatively well-documented works. 


\section{CONSERVATION STATUS}

All too often, freshwater mussel populations are referred as objects of study for their noticeable decline in different part of the world. Once they were the most abundant bivalve mollusc in ancient rivers around the world, but now many of them are declining in all countries, with species nearly extinct in many areas. The causes of this decline are not fully understood, and have become alarmingly frequent and widespread over the past 20 years, with a number of shortterm die-offs going largely unexplained but documented to some degree (Neves, 1987; Sparks et al., 1990; Fleming et al., 1995). Better documentation seems to be available for longer-term declines (Busby and Horak, 1993; Layzer et al., 1993; Williams et al., 1993). In many cases, alteration and degradation of the freshwater habitat like destruction of dams, modification of channels along with the introduction of non-indigenous mollusc, it seemed to play a central role (Williams et al., 1993; Saunders et al., 2002). A total of 200 unionoid species are on the IUCN Red List: 5 in Eurasia, 5 in Brazil, 1 in Australia, and the remaining 189 in the United States. Within the United States and Canada, 202 of the nearly 300 unionid species known are listed by the Natural Heritage Network as presumed extinct, possibly extinct, critically endangered, or vulnerable. In the United States alone, 37 species are presumed extinct or possibly extinct (Master et al., 2000). In Italy, five species of Unionoidae are present. Anodonta cygnea (Linnaeus, 1758), Sinanodonta woodiana (Lea, 1834), Microcondylaea compressa (Menke, 1830), Unio elongatulus (Pfeiffer, 1825) and Margaritifera auricularia (Spengler, 1793). Among them, M. compressa (= M. bonellii) is considered vulnerable in Italy and at the European level (Cuttelod et al., 2011; IUCN, 2015.4 ${ }^{1}$ ) and is subject to management measures in European Union by the Annex V of the "Habitats Directive." U. elongatulus (=U. mancus) is subject to management measures in European Union by the Annex V of the "Habitats Directive." Margaritifera auricularia is currently listed as Critically Endangered at the European level (Cuttelod et al., 2011; IUCN, 2015.4). In the 1980's it was considered to be nearly extinct, then was object of an European Action Plan and conservation programs to determine suitable fish hosts and levels of tolerance to pollution.

The unionid group also include many alien species. According to the IUCN Red List of Threatened Species (Version 2015.4), the Chinese pond mussel $S$. woodiana is the largest freshwater bivalve (valve length of up to about $30 \mathrm{~cm}$ ) and the fastest spreading, considered Invasive Alien Species in Europe (Cummings, 2011). This mollusc species originates from East and South-East Asia. The first record from Europe goes back to 1984 in Ungheria after its introduction in Danubian Basin (Petró, 1984) with some data for 1979 in Romania (Sárkány-Kiss, 1986; Frank et al., 1990). It was found in Italy for the first time between 1989 and 1996 (Manganelli et al., 1998; Watters, 1999), and in about 25 years, it formed colonies in 12 Italian regions (De Vico et al., 2007; Guarneri et al., 2014).

${ }^{1}$ I.U.C.N. (2015). IUCN Red List of Threatened Species. Version 2015.4. Available on: www.iucnredlist.org. Downloaded on 30 May 2016.

\section{ECOTOXICOLOGY}

In the last years, evaluation of stressor impacts upon freshwater mussel communities has progressed to distinct phases of investigation. Among them, greater emphasis is placed on the enhancement of methodologies to guide sampling or monitoring programs toward well-suited objectives that offer greater perspective and resolution of mussel community or population status. The need for balanced guidance ranges from field to laboratory consideration of evaluative tests [American Society for Testing and Materials (ASTM), 2005], as well as surveying, monitoring and sampling acceptability [American Society for Testing and Materials (ASTM), 2001; Strayer and Smith, 2003]. These refined methods support different monitoring approaches taking into account water quality parameters, discharge limits, or even impacts of large-scale disturbance (Farris and Van Hassel, 2006; Collins et al., 2008; Grabarkiewicz and Davis, 2008).

Among the families of freshwater bivalves, there are different reasons for their use in eco-toxicological research. Firstly, the Dreissenidae, and to a lesser extent, the Sphaeriidae, have fulfilled the traditional role of eco-toxicological research organisms. These bivalve families have supported a large percentage of basic research on contaminant uptake, toxico-kinetics, and toxicity testing due in part to their broad distribution, abundance, high reproductive potential, and ease of collection and laboratory culture. The Unionidae, in particular, has emerged as a critical group for a consideration in the field of ecotoxicology over the past 20 years because of their high sensitivity to chemical exposures and a variety of other environmental stressors, on respect to other group of organisms (IUCN, 2015). Many of the current researchers conducted ecotoxicology studies on these organisms because of their sensitivity to a variety of environmental disturbance, ease of collection and handling, and/or the lack of reliable information to support conservation and management. About their employment to assess genotoxicity and their use as animal tests (Makala and Oikari, 1990; Mersch and Beauvais, 1997), Valenti et al. (2005) reported that the results provided by experimental toxicity tests are critical for their conservation. Numerous laboratory studies have been conducted on freshwater mussels in order to understand the role of contaminants in the decline of the populations (Valenti et al., 2005; Ingersoll et al., 2006). In these studies, early life stages of several mussels species other than juveniles and adults, have been considered (Cherry et al., 2002; Ingersoll et al., 2006). As a matter of fact, most Unionids have a complex reproductive cycle including an ectoparasitic stage on fish, the glochidia. After fertilization, eggs develop to larvae called glochidia that mature in specialized chambers, called marsupia, of the female's gills (Figure 1B). Glochidia are released into the water and attach to the gills or fins of a suitable host fish. After one to several weeks of the parasitic stage, glochidia transform to juvenile mussels, leave the fish host, and fall to the torrent or bottom of lakes starting the free-living juvenile stage. Many studies indicate that glochidia and juvenile mussels are more sensitive to some chemicals when compared to commonly tested aquatic organisms like cladoceran, amphipod and different 


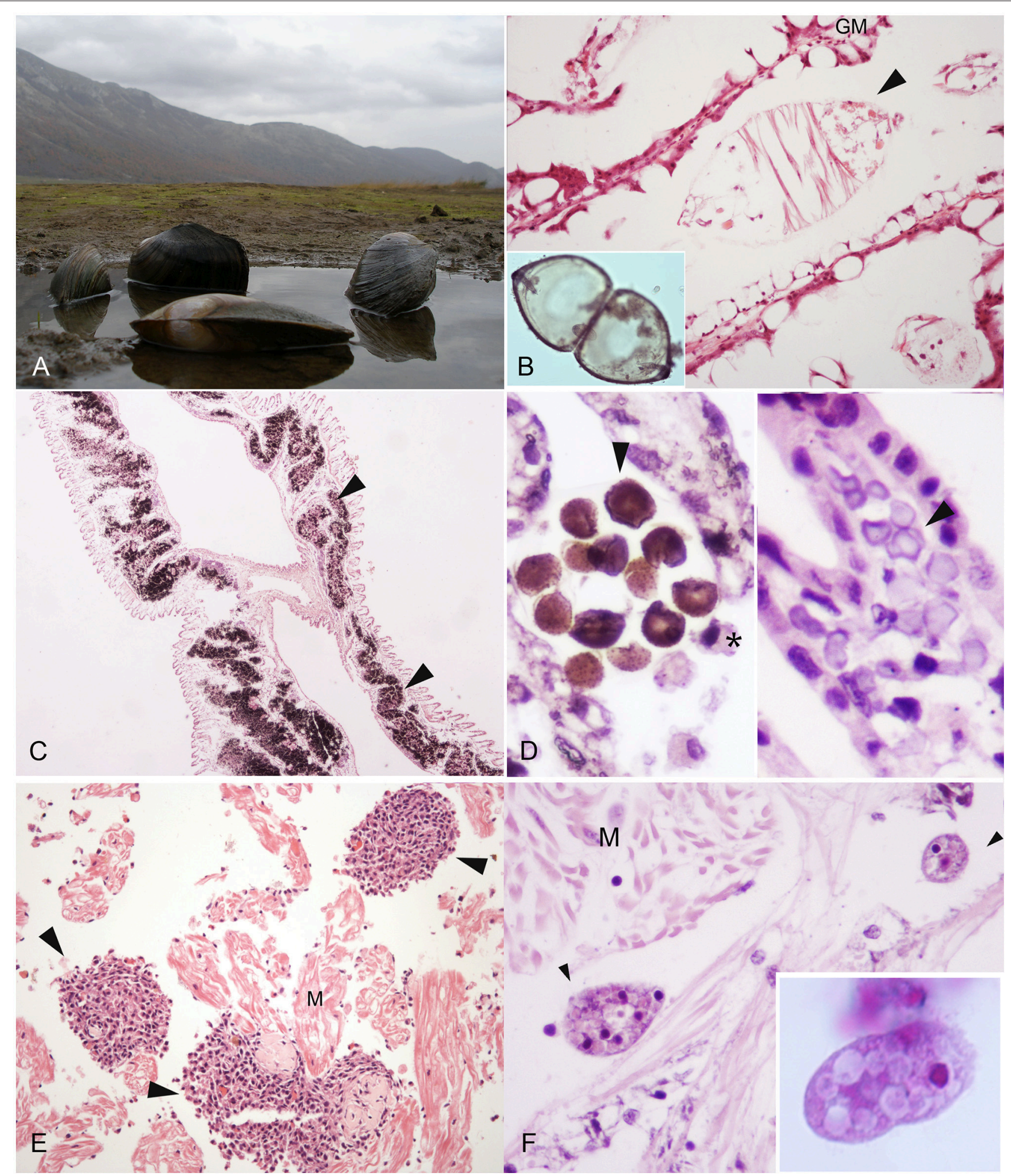

FIGURE 1 | Macro-microscopical observation of pathogen and disease in freshwater mussel species. (A) Anodonta cygnea from Matese Lake (Caserta, Campania region) H\&E; (B) Glochidium of Anodonta woodiana in the gill marsupium (GM), H\&E, 40X; (C) Calcium Concretions (arrowheads) in the gills of Unio pictorum visible in black, Von Kossa Stain, 20X; (D) Calcium concretions in gills: Stain for Copper (Left), H\&E (right) 40X; (E) Inflammatory nodulation (arrowheads) in heart muscle fibers (M) in A. anatina E\&E, 40X. (F) Conchophthirus spp. (arrowheads) in the mantle of Unio pictorum, E\&E, 100X. *Haemocyte (M): muscle. 
fish species (Ingersoll et al., 2006; Bringolf et al., 2007a,b; Wang et al., 2007a,b; Gillis et al., 2008). The American Society for Testing and Materials (ASTM) (2006) provides a list of recommended test conditions for toxicity tests. Along with that, the development of physiological and biochemical tests or biomarkers of sub-lethal exposure are critical in assessing the condition of unionids. Toxicity end-points have also been established including survival, growth, bioaccumulation and behavior, along with numerous molecular biomarkers such as glycogen concentration, DNA strand breakage, cellulolytic enzyme activity, and AChE inhibition [American Society for Testing and Materials (ASTM), 2006; Kolarević et al., 2013]. Several textbooks and review articles have been written on the use of biomarkers in a wide range of aquatic organisms (McCarthy and Shugart, 1990; Van der Oost et al., 2003), many of these have application in unionids (Farris and Van Hassel, 2006). In particular, there have been studies that have assessed mussel sensitivity to a range of environmental contaminants including pesticides (Keller and Ruessler, 1997), ammonia (Augspurger et al., 2003; Newton and Bartsch, 2007), mercury (Valenti et al., 2005), cadmium (Markich et al., 2003; Wang et al., 2007b). However, for a given chemical, toxicity can vary by an order of magnitude among life stage and species (Cherry et al., 2002; Augspurger et al., 2003). About heavy metals and pollutants like polycyclic aromatic hydrocarbons (PAHs), are commonly released into the environment by anthropogenic activities. In mussels, study on bioaccumulation have been conducted, in some case concluding that some species, like E. complanata, can be an effective biomonitor of PAH and PCB concentrations in aquatic systems (Gewurtz et al., 2003). Moreover, when exposed to elevated metal concentrations in their environment, molluscs are known to accumulate metals to high levels in their tissues (Hemelraad et al., 1986; Couillard et al., 1993). Metal tolerance in such organisms involve the sequestration of metals in non-toxic forms. Among the available sequestration sites in the intracellular space, high affinity metalbinding proteins such as metallothioneins (MTs), lysosomes and granules, also called concretions, are reported (Mason and Jenkins, 1995). Metallothioneins are low molecular weight, cysteine-rich metal-binding proteins and biochemical indicator of pollutant exposure (Roesijadi, 1992). Gill metallothionein concentrations in the freshwater unionid bivalve Pyganodon grandis vary both spatially and temporally along cadmium gradients (Couillard et al., 1993). In addition to metallothionein, unionids also produce calcium concretions (Figures 1C,D), present at the level of connective tissue of the gills (Silverman et al., 1987), in the mantle (Adams et al., 1997) and in the digestive gland epithelia (Pynnonen et al., 1987). The calcium present in the concretions is generally associated to phosphate (Mason and Jenkins, 1995), present either as orthophosphate (PO4), pyrophosphate (P2O7) or their protonated forms (Jefree et al., 1993). These structures are a calcium reservoir, serving as a source of calcium for shell development (Silverman et al., 1985), but can also play a role in the detoxification of metals (Simkiss, 1981; Mason and Simkiss, 1982; Lautiè et al., 1988).

\section{BIOLOGICAL AGENTS AND DISEASES}

An important step in comprehending freshwater mussel health status is to gain information about pathogens. Parasites and infectious agents with related lesions (i.e., inflammations and regressive phenomena) of this group is poorly described in literature. Among the reported pathogens, bacteria, protozoan and metazoan parasites like trematodes, nematodes, mites, and ciliates (Conchophthirus spp.), have the potential to decrease the fitness of the host unionid, but their role in diseases has not been well established (Table 1). About diagnostic procedures, techniques were described by Southwick and Loftus (2003). Moreover, Fuller (1974), McMahon and Bogan (2001), Smith (2001) and Grizzle and Brunner (2009), presented a brief review of the diseases of freshwater mussels. Presence of inflammatory capsules and infiltrates have been observed in Anodonta woodiana linked to bacterial infection (Carella et al., 2013a; Figure 1E).

Evidence for viral diseases has been found in only one species of freshwater bivalve, a Chinese pearl mussel, Hyriopsis cumingii. The Hyriopsis cumingii, Lea virus disease, which is often referred to Lea plague disease (HCPD), was first reported in 1980s. Next reports used light and transmission electron microscopic (TEM) analysis of tissues from diseased bivalve mussels showed that the HCPD was associated with an arenavirus agent termed Hyriopsis cumingii Lea plague Virus (HcPV) (Zhang et al., 1986; Zhong et al., 2011).

Differently to marine bivalves, little is known about bacterial diseases of this group of molluscs. All the reports present in literature still are uncertain about their role as pathogens/symbionts. In general, the importance of bacteria as etiological agent of diseases in marine bivalves is mostly reported in intensively cultured species. Previous studies from Jenkinson and Ahlstedt (1987) reported die-offs of unionids from the Tennessee River in the years 1985-1986 and observed the presence of different species of bacteria in the connective tissue and in the digestive gland of affected mussels, but related to scarce haemocytosis.

About protozoan reports, in unionids the most common group reported belong to the genus Conchophthirus spp. (family Conchophthiridae). Species of this genus are only found in freshwater bivalves, and are among the most common organisms in this animal group. The body of these ciliates is flattened, elliptical in profile, with the mouth near the middle of the body (Fenchel, 1965; Antipa and Small, 1971a; Figure 1F). They have dense cilia over their entire surface and an average length of about $100 \mu \mathrm{m}$. Conchophthirus spp. move within the mantle cavity and are not firmly attached to the host. The reported species by Kelly (1899) are Conchophthirus anodontae and Conchophthirus curtus were of 30 of the 44 species of unionids examined from Illinois and Pennsylvania.

Antipa and Small (1971b) described the presence of the ciliate Heterocinetopsis unionidarum (Ancistrocomidae) in 2 of the 4 species of mussels examined in the one locality where it occurred. Parasitized unionids like Anodonta grandis and Lasmigona complanata didn't show specific harmful effects from 
TABLE 1 | Pathogens (virus, fungi, protozoa, and metazoa) described in Unionids.

\begin{tabular}{|c|c|c|c|c|}
\hline Regnum & Phylum & Class & Species & Bivalve hosts \\
\hline Virus & Arenavirus & & Lea plague Virus (HcPV) & Hyriopsis cumingii \\
\hline Fungi & Heterokonta & Oomycota & Oomycetes saprofites & Unio spp. \\
\hline \multirow[t]{3}{*}{ Protozoa } & Ciliophora & & Conchophthirus spp. & $\begin{array}{l}\text { Elliptio complanata, Anodonta marginata, Anodonta } \\
\text { implicata, Pyganodon cataracta, Lampsilis radiata, Lampsilis } \\
\text { cariosa, Alasmidonta undulata, Anodonta cygnea }\end{array}$ \\
\hline & & & Heterocinetopsis unionidarum & Pyganodon (=Anodonta) grandis, Lasmigona complanata \\
\hline & & & Trichodina unionis & Anodonta cygnea, Unio spp. \\
\hline \multirow[t]{11}{*}{ Metazoa } & Platelmintes & Trematodes Digenea & Aspidogaster conchicola & Indonaia caerulea, Corbicula striatella, Lamellidens corrianus \\
\hline & & & Cotylaspis insignis & \\
\hline & & & Cotylogaster occidentalis & \\
\hline & & & Lophotaspis interiora & \\
\hline & & & Bucephalus polymorphus & Unio pictorum, Dreissena spp. \\
\hline & & & Rhipidocotyle spp. & Unio pictorum, A. anatina \\
\hline & & & Polylekithum spp. & A. plicata \\
\hline & & Nematoda & Hysterothylacium sp. & Diplodon suavidicus \\
\hline & Artropoda & Copepods & Paraergasilus rylovi & Anodonta piscinalis \\
\hline & & Mites & Unionicola spp. & $\begin{array}{l}\text { Unio complanata, Unio gibbosus U. ligamentinus } U \text {. } \\
\text { intermedia, A. fragilis, A. footiana, A. cataracta, Anodonta } \\
\text { cygnea, A. anatina, Elliptio complanata }\end{array}$ \\
\hline & & & Najadicola spp. & \\
\hline
\end{tabular}

this protozoa, present at the gills and palps. Other reported ciliates belong to the genus Tricodina. This genus and related genera (Peritrichia: Trichodinidae) include numerous species reported as fish and marine bivalve parasites, but a few species are found in unionids. Trichodina unionis is found in the mantle cavity of Anodonta cygnea and Unio spp. in Europe (Fenchel, 1965). Prevalence approaches $100 \%$ in some populations but with only about 10 per host. Diameter of T. Unionis is about 70-100 $\mu \mathrm{m}$ (Raabe and Raabe, 1961; Fenchel, 1965). The most common location of this organism is on the labial palps, and less often the gills (Raabe and Raabe, 1961). Trichodina sp. was observed in unionids collected in Illinois (Antipa and Small, 1971b) and North Carolina (Chittick et al., 2001). Histological examination did not reveal lesions associated with Trichodina sp. (Chittick et al., 2001). Other ciliates of unionids are the scyphidiid peritrich Mantoscyphidia sp., and low numbers of a scuticociliatid ciliate on the gills of Elliptio complanata in North Carolina (Chittick et al., 2001).

Among Metazoan parasites, larvae of nematodes belong to the genus Hysterothylacium (Nematoda, Anisakidae) parasitizing the pericardial cavity of Diplodon suavidicus from the Amazon basin (Brazil) were reported by Lopes et al. (2011), but no lesions pathogen-specific are described.

On the other side, Trematodes of different families are reported in this group of animals as mussels result as intermediate hosts for digenean trematodes. The family of
Aspidogastridae commonly parasitize freshwater mollusks. Four species of aspidogastrids have been reported: Aspidogaster conchicola, Cotylaspis insignis, Cotylogaster occidentalis, and Lophotaspis interiora. Two of these species, are among the most common symbionts of unionids, are widely distributed, and are found in several hosts in North America (Huehner, 1984; Hendrix et al., 1985). Bucephalid trematodes in unionids belong to the genus Rhipidocotyle spp., recently called Bucephalus polymorphus (Kelly, 1899; Yanovich and Stadnichenko, 1997). In Unio pictorum, Baturo (1977) found sporocysts of Rhipidocotyle campanula and provided a detailed description of the developmental stages of this parasite. In Europe two species of Rhipidocotyle in the unionid Anodonta anatina are reported: Rhipidocotyle campanula and Rhipidocotyle fennica (Gibson et al., 1992; Muller et al., 2015). In North America the Rhipidocotyle spp. identified as parasite unionids are Rhipidocotyle septpapillata (Kniskern, 1952) and Rhipidocotyle papillosa (Woodhead, 1930, 1936). The most serious effect of bucephalid trematodes is host sterility with gonadal tissues replaced by sporocysts also accompanied to follicle fibrosis. Additional lesions also can occur at kidney level (Kelly, 1899; Kniskern, 1952; Taskinen et al., 1997; Yanovich and Stadnichenko, 1997).

Moreover, water mites like Unionicola spp. (Hydrachnidia: Unionicolidae) commonly occur as symbionts of freshwater mussels. More than half of the described species are considered as symbionts and in 2013 Edwards and Vidrine published a book 
on the topic, with information on biogeography, classification, mussel-mite interactions, coevolution and phylogenetics. Three genera are known as symbionts of freshwater molluscs, like Dockovdia, Najadicola, and Unionicola and generally they live on the gills, mantle or foot of their hosts (Vidrine, 1996; Edwards and Vidrine, 2013).

\section{NEOPLASTIC DISEASES}

During the past 50 years a considerable literature has been published on spontaneous and experimentally-induced tumors in invertebrates. Invertebrate neoplasia have been described in different taxonomic groups, like sipunculids, annelids, ascidians, arthropods, insects and bivalve with economic interest (Scharrer and Lochhead, 1950; Rosenfield et al., 1994; De Vico and Carella, 2015). In particular, gonadal and haemic neoplasia of marine bivalves are the most common, and present the characteristics of malignant tumors (Carella et al., 2013b). Others, less frequent type, are the tumors arise from epithelia, muscle and connective tissue, mostly classified as benign, with neither invasive behavior nor mitotic figures. These neoplasms like polypoid growths of the foot, mantle and pericardium have been found repeatedly in Unionid molluscs (Pauley, 1967a,b; Sparks, 1985) like Anodonta cygnea (Williams, 1890; Collinge, 1891), A. implicata (Butros, 1948) and A. californiensis (Pauley, 1967b). A fibroma, lined by simple columnar ciliated epithelium, arising from the palp of the mussel A. implicata, have been reported. Williams (1890) reported a pedunculated tumor, composed of glandular and muscle cells while Collinge (1891) also observed two tumors from the same species from the same species of freshwater mussel, with no microscopical descriptions.

\section{CONCLUSION REMARKS}

In recent years, considerable progress has been made in our understanding of aquatic animal disease (Cockerell and

\section{REFERENCES}

Adams, S. M., Shorey, C. D., and Byrne, M. (1997). An ultrastructural and microanalytical study of metal-ion content in granular concretions of the freshwater mussel Hyridella depressa. Micron 28, 1-11. doi: 10.1016/S09684328(97)00003-6

American Society for Testing and Materials (ASTM) (2001). Standard Guide for Conducting in Situ Field Bioassays with Caged Bivalves, Annual Book of ASTM Standards, Vol. 11.05, Philadelphia, PA: ASTM, E2122-02.

American Society for Testing and Materials (ASTM) (2005). Standard Guide for Conducting Laboratory Toxicity Tests with Freshwater Mussels, Annual Book of Standards, Vol. 11.05, Philadelphia, PA: ASTM, E2455-05.

American Society for Testing and Materials (ASTM) (2006). Standard Guide for Conducting Laboratory Toxicity Tests with Freshwater Mussels (ASTM E245506), ASTM Annual Book of Standards, Vol. 11.05, West Conshohocken, PA: ASTM.

Antipa, G. A., and Small, E. B. (1971a). A redescription of Conchophthirus curtus Engelmann, 1862 (Protozoa, Ciliatea). J. Protozool. 18, 491-503. doi: 10.1111/j.1550-7408.1971.tb03361.x

Antipa, G. A., and Small, E. B. (1971b). The occurrence of thigmotrichous ciliated protozoa inhabiting the mantle cavity of unionid molluscs of Illinois. Trans. Am. Microsc. Soc. 90, 463-472. doi: 10.2307/3225461
Patterson, 2005; Boorman, 2008). Lately, research studies on bivalve pathology and immunity has been growing, demonstrating that invertebrates are capable of mounting a wide and complex immune response, with discovered molecular mechanisms behind this diversity unraveled in several aquatic species (Song et al., 2010).

Study results indicates that pathogens and diseases have the potential to impact conservation of this endangered aquatic fauna (Williams et al., 1993; Starliper, 2011). Comparative and anatomic pathology are an important component in ecological risk assessment, considering physical and biological stressors, as well as chemical contaminants (USEPA, 1992). Pathologists, Ecologists, environmental experts and governing organizations at all levels must be educated regarding the value of anatomic pathology in holistic risk evaluation in aquatic animal conservation.

Additional research is also needed to determine whether other types of pathogens are present in this group of bivalves. This increased emphasis on non-mammalian models is likely to growth the use of aquatic species in risk assessment, further highlighting the need to ensure a strong, optimally trained workforce in aquatic pathology that will use a standard approach in disease diagnosis.

\section{AUTHOR CONTRIBUTIONS}

FC, Pathology part. GV, University of Naples Federico IITechnical support. NM, University of Naples Federico II-Conservation status od freshwater mussel expert. GD, University of Naples Federico II-Pathology part.

\section{ACKNOWLEDGMENTS}

The authors acknowledge Nucleo Carabinieri Subacquei of Naples for their technical support. This paper was supported in part by a grant from the Ente Provincia di Caserta.
Augspurger, T., Keller, A. E., Black, M. C., Cope, W. G., and Dwyer, F. J. (2003). Water quality guidance for the protection of freshwater mussels (Unionidae) from ammonia exposure. Environ. Toxicol. Chem. 22, 2569-2575. doi: 10.1897/02-339

Baturo, B. (1977). Bucephalus polymorphus Baer, 1827 and Rhipidocotyle illense (Ziegler, 1883) (Trematoda, Buce- phalidae): morphology and biology of developmental stages. Acta Parasitol. Pol. 24, 203-220.

Boorman, G. A. (2008). How do we create and maintain toxicologic pathologists? Scope Newsl. Soc. Toxicol. Pathol. 26, 1-3.

Bringolf, R. B., Cope, W. G., Barnhart, M. C., Mosher, S., Lazaro, P. R., and Shea, D. (2007b). Acute and chronic toxicity of pesticide formulations (atrazine, chlorpyrifos, and permethrin) to glochidia and juveniles of Lampsilis siliquoidea. Environ. Toxicol. Chem. 26, 2101-2107. doi: 10.1897/06-555R.1

Bringolf, R. B., Cope, W. G., Eads, C. B., Lazaro, P. A., Barnhart, M. C., and Shea, D. (2007a). Acute and chronic toxicity of technical-grade pesticides to glochidia and juveniles of freshwater mussels (Unionidae). Environ. Toxicol. Chem. 26, 2086-2093. doi: 10.1897/06-522R.1

Busby, W. H., and Horak, G. (1993). "Unionid mussels in Kansas: overview of conservation efforts and harvest regulations," in Conservation and Management of Freshwater Mussels. Proceedings of a UMRCC Symposium 1992, eds K. S. Cummings, A. C. Buchanan, and L. M. Koch (St. Louis, MO), 50-55.

Butros, J. (1948). A tumor in a freshwater mussel. Cancer Res. 8, 270-272. 
Carella, F., Figueras, A., Novoa, B., and De Vico, G. (2013b). Cytomorphology and PCNA expression pattern in bivalves Mytilus galloprovincialis and Cerastoderma edule with haemic neoplasia. Dis. Aquat. Org. 105, 81-87. doi: 10.3354/dao02612

Carella, F., Maio, N., Aceto, S., and De Vico, G. (2013a). "New records of Sinanodonta woodiana (Lea, 1834) (Mollusca: Bivalvia: Unionidae) from Southern Italy with related pathologic condition. Wave Congress, 2013," VIII Symposium Internacionàl de Fauna Salvaje, 31 de Octubre y 3 de Noviembre de 2013 (Leon).

Cherry, D. S., Van Hassel, J. H., Farris, J. L., Soucek, D. J., and Neves, R. J. (2002). Site-specific derivation of the acute copper criteria for the Clinch River, Virginia. Hum. Ecol. Risk Assess. 8, 591-601. doi: 10.1080/10807030290 879844

Chittick, B., Stoskopf, M., Law, M., Overstreet, R., and Levine,. J. (2001). Evaluation of potential health risks to eastern elliptio (Elliptio complanata) (Mollusca: Bivalvia: Unionida: Unionidae) and implications for sympatric endangered freshwater mussel species. J. Aquat. Ecosyst. Stress Recovery 9, 35-42. doi: 10.1023/A:1013167520252

Cockerell, G. L., and Patterson, D. R. (2005). Closing the supply vs. demand gap for veterinary pathologists: a multifaceted problem in need of a multifaceted solution. Vet. Pathol. 42, 403-404. doi: 10.1354/vp.42-4-403-a

Collinge, W. C. (1891). Note on a tumour in Anodonta cygnea Linn. J. Anat. Physiol. Normal Pathol. 25, 154.

Collins, F. S., Gray, G. M., and Bucher, J. R. (2008). Toxicology. Transforming environmental health protection. Science 319, 906-907. doi: 10.1126/ science. 1154619

Couillard, Y., Campbell, P. G. C., and Tessier, A. (1993). Response of metallothionein concentrations in a freshwater bivalve (Anodonta grandis) along an environmental cadmium gradient. Limnol. Oceanogr. 38, 299-313. doi: 10.4319/lo.1993.38.2.0299

Cummings, K. (2011). Sinanodonta woodiana. The IUCN Red List of Threatened Species 2011: e.T166313A6198609. doi: 10.2305/IUCN.UK.20112.RLTS.T166313A6198609.en

Cuttelod, A., Seddon, M., and Neubert, E. (2011). European Red List of Non-marine Molluscs. Luxembourg: Publications Office of the European Union.

De Vico, G., and Carella, F. (2015). Tumors in invertebrates: molluscs as an emerging animal model for human cancer. ISJ 12, 19-21.

De Vico, G., Maio, N., and Castagnolo, L. (2007). Prima segnalazione di Anodonta (Sinanodonta) woodiana (Lea, 1834) (Mollusca: Bivalvia: Unionidae) per il Sud Italia. Notiziario S.I.M. 25, 23-25.

Edwards, D. D., and Vidrine, M. F. (2013). Mites of Freshwater Mollusks. Eunice: Malcolm F. Vidrine.

Farris, J. L. and Van Hassel, J. H., (2006). Freshwater Bivalve Ecotoxicology, Society of Environmental toxicology and Chemistry (SETAC). Boca Raton, FL: CRC Press, Taylor and Francis. 375.

Fenchel, T. (1965). Ciliates from Scandinavian molluscs. Ophelia 2, 71-174. doi: 10.1080/00785326.1965.10409598

Fleming, W. J., Augspurger, T. P., and Alderman, J. A. (1995). Freshwater mussel die-off attributed to anticholinesterase poison. Environ. Toxicol. Chem. 14, 877-879. doi: 10.1002/etc.5620140520

Frank, C., Jungbluth, J., and Richnovszky, A. (1990). Die Mollusken der Donau vom Schwarzwald bis zum Schwarzen Meer (Eine monographische Darstellung). Budapest: Richnovsky and Berczik. 142.

Fuller, S. L. H. (1974). "Clams and mussels (Mollusca: Bivalvia)," in Pollution Ecology of Freshwater Invertebrates, eds C. W. Hart Jr. and S. L. H. Fuller (New York, NY: Academic Press), 215-273.

Gewurtz, S. B., Lazar, R., and Haffner, G. D. (2003). Biomonitoring of bioavailable PAH and PCB water concentrations in the detroit river using the freshwater mussel, elliptio complanata. J. Great Lakes Res. 29, 242-255. doi: 10.1016/S0380-1330(03)70430-4

Gibson, D. I., Taskinen, J., and Valtonen, E. T. (1992). Studies on bucephalid digeneans parasitising molluscs and fishes in Finland. II. The description of Rhipidocotyle fennica n. sp. and its discrimination by principal components analysis. Syst. Parasitol. 23, 67-79. doi: 10.1007/BF00008011

Gillis, P. L., Mitchell, R. J., Schwalb, A. N., McNichols, K. A., Mackiea, G. L., Wood, C. M., et al. (2008). Sensitivity of the glochidia (larvae) of freshwater mussels to copper: Assessing the effect of water hardness and dissolved organic carbon on the sensitivity of endangered species. Aquat. Toxicol. 88, 137-145. doi: 10.1016/j.aquatox.2008.04.003
Grabarkiewicz, J. D., and Davis, W. S. (2008). An Introduction to Freshwater Mussels As Biological Indicators Including Accounts of Interior Basin, Cumberlandian, and Atlantic Slope Species. Washington, DC: United States Department of Environmental Protection. EPA-260-R-08-015. U.S. Environmental Protection Agency, Office of Environmental Information.

Grizzle, J. M., and Brunner, C. J. (2009). Infectious diseases of freshwater mussels and other freshwater bivalve mollusks. Rev. Fish. Sci. 17, 425-467. doi: 10.1080/10641260902879000

Guarneri, I., Popa, O. P., Gola, L., Kamburska, L., Lauceri, R., Lopes-Lima, M., et al. (2014). A morphometric and genetic comparison of Sinanodonta woodiana (Lea, 1834) populations: does shape really matter? Aquat. Invasions 9, 183-194. doi: 10.3391/ai.2014.9.2.07

Hanlon, S. D. (2003). Releasing mussels to recovering waters. Endanger. Spec. Bull. $28,8-9$.

Hemelraad, J., Holwerda, D. A., and Zandee, D. I. (1986).Cadmium kinetics in freshwater clams. III. The pattern of cadmium accumulation in Anodonta cygnea. Arch. Environ. Contam. Toxicol. 15, 1-7. doi: 10.1007/BF01055243

Hendrix, S. S., Vidrine, M. F., and Hartenstine, R. H. (1985). A list of records of freshwater aspidogastrids (Trematoda) and their hosts in North America. Proc. Helminthol. Soc. Wash. 52, 289-296.

Huehner, M. K. (1984). Aspidogastrid trematodes from freshwater mussels in Missouri with notes on the life cycle of Cotylaspis insignis. Proc. Helminthol. Soc. Wash. 51, 270-274.

Ingersoll, C. G., Kernaghan, N. J., Gross, T. S., Bishop, C. D., Wang, N., and Roberts, A. (2006). "Laboratory toxicity testing with freshwater mussels," in Freshwater Bivalve Ecotoxicology, eds J. L. Farris and J. H. van Hassel (Pensacola, FL: SETAC), 95-134.

Jefree, R. A., Markich, S. J., and Brown, P. L. (1993). Comparative accumulation of alkaline-earth metals by two freshwater mussel species from the Nepean river, Australia: consistencies and a resolved paradox. Aust. J. Freshw. Res. 44, 609-634. doi: 10.1071/MF9930609

Jenkinson, J. J., and Ahlstedt, S. A. (1987). "Mussel die-offs downstream from pickwick landing dam, tennessee river, 1985 and 1986," in Proceedings of the Workshop on Die-offs of Freshwater Mussels in the United States, 23-25 June 1986, ed R. J. Neves (Davenport: U.S. Fish and Wildlife Service and Upper Mississippi River Conservation Committee), 29-38.

Jones, J. W., Mair, R. A., and Neves, R. J. (2005). Factors affecting survival and growth of juvenile freshwater mussels cultured in recirculating aquaculture systems. N. Am. J. Aquacult. 67, 210-220. doi: 10.1577/A04-055.1

Keller, A. E., and Ruessler, D. S. (1997). The toxicity of malathion to unionid mussels: relationship to expected environmental concentrations. Environ. Toxicol. Chem. 16, 1028-1033. doi: 10.1002/etc.5620160524

Kelly, H. M. (1899). A statistical study of the parasites of the Unionidae. Bull. Ill. State Lab. Nat. Hist. 5, 399-418.

Kniskern, V. B. (1952). Studies on the trematode family Bucephalidae Poche, 1907, Part II: the life history of Rhipidocotyle septpapillata Krull, 1934. Trans. Am. Microsc. Soc. 71, 317-340. doi: 10.2307/3223462

Kolarević, S., Kneževic-Vukcevic, J., Paunovic, M., Kracun, M., Vasiljevic, B., Tomovic, J., et al. (2013). Monitoring of DNA damage in haemocytes of freshwater mussel Sinanodonta woodiana sampled from the Velika Morava River in Serbia with the comet assay. Chemosphere 93, 243-251. doi: 10.1016/j.chemosphere.2013.04.073

Lautiè, N., Carru, A. M., and Truchet, M. (1988). Bioaccumulation naturelle de manganese et de fer dans les tissus mous d'Anodonta cygnea (mollusque lamellibranche, metabranchie'). Malacologia 29, 405-417.

Layzer, J. B., Gordon, M. E., and Anderson, R. M. (1993). Mussels: the forgotten fauna of regulated rivers. A case study of the Caney Fork River. Reg. Rivers Res. Manage. 8, 63-71. doi: 10.1002/rrr.3450080110

Lopes, L. P., Pimpão, D. M., Takemoto, R. M., Malta, J. C., and Varrella, A. M. (2011). Hysterothylacium larvae (Nematoda, Anisakidae) in the Freshwater mussel Diplodon suavidicus (Lea, 1856) (Mollusca, Unioniformes, Hyriidae) in Aripuan $\gamma$ River, Amazon, Brazil. JIP 106, 357-359. doi: 10.1016/j.jip.2010.12.002

Makala, P., and Oikari, A. O. J. (1990). Uptake and body distribution of chlorinated phenolic in the freshwater mussel, Anodonta anatina L. Ecotox. Environ. Saf. 20, 354-362. doi: 10.1016/0147-6513(90)90012-T

Manganelli, G., Bodon, M., Favilli, L., Castagnolo, L., and Giusti, F. (1998). Checklist delle specie della fauna d'Italia, molluschi terrestri e d'acqua dolce. Errata ed addenda, 1. Bollettino Malacologico 33, 151-156. 
Markich, S. J., Brown, P. L., Jeffree, R. A., and Lim, R. P. (2003). The effects of dissolved organic carbon on the toxicity of cadmium and copper to a freshwater bivalve: further support for the extended free ion activity model. Arch. Environ. Contam. Toxicol. 45, 479-491. doi: 10.1007/s00244-003-2175-x

Mason, A. Z., and Jenkins, K. D. (1995). "Metal detoxification in aquatic organisms," in Metal Speciation and Bioavailability in Aquatic Systems, eds A. Tessier and D. R. Turner (New York, NY: John Wiley Sons), 479-607.

Mason, A. Z., and Simkiss, K. (1982). Sites of mineral deposition in metal accumulating cells. Exp. Cell. Res. 139, 383-391. doi: 10.1016/00144827(82)90263-4

Master, L. L., Stein, B. A., Kutner, L. S., and Hammerson, G. A. (2000). "Vanishing assets: conservation status of U.S. species," in Precious Heritage: The Status of Biodiversity in the United States, eds B. A. Stein, L. S. Kutner, and J. S. Adams (New York, NY: Oxford University Press), 93-118.

McCarthy, J. F., and Shugart, L. R. (1990). "Biological markers of environmental contamination," in Biomarkers of Environmental Contamination, eds J. F. McCarthy and L. R. Shugart (Boca Raton, FL: Lewis), 3-16.

McMahon, R. F., and Bogan, A. E. (2001). "Mollusca: Bivalvia," in Ecology and Classification of North American Freshwater Invertebrates, 2nd Edn., eds J. H. Thorp and A. P. Covich (San Diego, CA: Academic Press), 331-429.

Mersch, J., and Beauvais, M. N. (1997). The micronucleus assay in the zebra mussel, Dreissena polymorpha, to in situ monitor genotoxicity in freshwater environments. Mutat. Res. 393, 141-149. doi: 10.1016/S1383-5718(97)00099-5

Muller, T., Czarnoleski, M., Labecka, A. M., Cichy, A., Zajac, K., and DragoszKluska, D. (2015). Factors affecting trematode infection rates in freshwater mussels Hydrobiologia 742, 59-70. doi: 10.1007/s10750-014-1965-7

Neves, R. J. (1987). "Recent die-offs of freshwater mussels in the United States: an overview," in Proceedings of the Workshop on Die-offs of Freshwater Mussels in the United States, ed R. J. Neves (Davenport, IA).

Newton, T. J., and Bartsch, M. R. (2007). Lethal and sublethal effects of ammonia to juvenile Lampsilis mussels (Unionidae) in sediment and water-only exposures. Environ. Toxicol. Chem. 26, 2057-2065. doi: 10.1897/06-245R.1

Pauley, G. B. (1967a). A tumor-like growth on the foot of a freshwater mussel (Anodonta californiensis). J. Fish. Res. Board Can. 24, 679-682.

Pauley, G. B. (1967b). Four freshwater mussels (Anodonta californiensis) with pedunculated adenomas arising from the foot. J. Invertebr. Pathol. 9, 459-466. doi: 10.1016/0022-2011(67)90124-3

Petró, E. (1984). The occurrence of Anodonta woodiana (Lea, 1834) (Bivalvia, Unionacea) in Hungary. Állattani Közlemények 71, 189-191.

Pynnonen, K., Holwerda, D. A., and Zandee, D. I. (1987). Occurrence of calcium concretions in various tissues of freshwater mussels and their capacity for cadmium sequestration. Aquat. Toxicol. 10, 101-114. doi: 10.1016/0166445X(87)90017-8

Raabe, J., and Raabe, Z. (1961). Urceolariidae from fresh-water and terrestrial mollusc in Poland. Acta Parasitol. Pol. 9, 141-151.

Roesijadi, G. (1992). Metallothioneins in metal regulation and toxicity in aquatic animals. Aquat. Toxicol. 22, 81-114. doi: 10.1016/0166-445X(92)90026-J

Rosenfield, A., Kern, F. G., and Keller, B. J. (1994). "Invertebrate neoplasia: initiation and promotion mechanisms," in NOAA Technical Memo NMFS-NE107 (Washington, DC).

Sárkány-Kiss, A. (1986). Anodonta woodiana (Lea, 1834) a new species in Romania (Bivalvia, Unionacea). Trav. Mus. Hist. Nat. Grigore Antipa 28, 15-17.

Saunders, D. L., Meeuwig, J. J., and Vincent, A. C. J. (2002). freshwater protected areas: strategies for conservation. Freshwater protected areas: strategies for conservation. Conserv. Biol. 16, 30-41. doi: 10.1046/j.1523-1739.2002.99562.x

Scharrer, B., and Lochhead, M. S. (1950). Tumors in the invertebrates: a review. Cancer Res. 10, 403-419.

Silverman, H., McNeil, J. W., and Deitz, T. H. (1987). Interactions of trace metals $\mathrm{Zn}, \mathrm{Cd}$ and $\mathrm{Mn}$ with Ca concretions in the gills of freshwater unionid mussels. Can. J. Zool. 65, 828-832. doi: 10.1139/z87-131

Silverman, H., Steffens, W. L., and Dietz, T. H. (1985). Calcium from extracellular concretions in the gills of freshwater unionid mussels is mobilized during reproduction. J. Exp. Zool. 236, 137-147. doi: 10.1002/jez.1402360204

Simkiss, K. (1981). Cellular discrimination processes in metal accumulating cells. J. Exp. Biol. 94, 317-327.

Smith, D. G. (2001). Pennak's Freshwater Invertebrates of the United States, 4th Edn. New York, NY: John Wiley and Sons.

Song, L., Wang, L., Qiu, L., and Zhang, H. (2010). "Bivalve Immunity," in Invertebrate Immunity, Vol. 708, ed K. Soderhall (New York, NY: Springer), 316.
Southwick, R. I., and Loftus, A. J. (2003). Investigation and Monetary Values of Fish and Freshwater Mussel Kills, Special Publication 30. Bethesda, MD: American Fisheries Society.

Sparks, A. K. (1985). Synopsis of Invertebrate Pathology. Exclusive of Insects. Amsterdam: Elsevier Science.

Sparks, R. E., Blodgett, K. D., Durham, L., and Horner, R., (1990). Determination Whether the Causal Agent for Mussel Die-offs in the Mississippi River is of Chemical or Biological Origin. Final Report, ILENR/RE-WR 90/09, Illinois Department of Energy and Natural Resources, Springfield, IL.

Starliper, C. E. (2011). "Pathogens and diseases of freshwater mussels in the United States: studies on bacterial transmission and depuration," in Bridging America and Russia with Shared Perspectives on Aquatic Animal Health. Proceedings of the Third Bilateral Conference between Russia and the United States, 12-20 July, 2009, held in Shepherdstown, West Virginia, eds R. C. Cipriano, A. W. Bruckner, and I. S. Shchelkunov (Landover, MD: Khaled bin Sultan Living Oceans Foundation), 47-55.

Strayer, D. L., and Smith, D. R. (2003). A Guide to Sampling Freshwater Mussel Populations, Monograph 8. Bethesda, MD: American Fisheries Society.

Taskinen, J., Mäkelä, T., and Valtonen, E. T. (1997). Exploitation of Anodonta piscinalis (Bivalvia) by trematodes: parasite tactics and host longevity. Annls. Zool. Fennici. 34, 37-46.

USEPA (1992). Framework for Ecological Risk Assessment. EPA/630/R-92-001. U.S. Washington, DC: Environmental Protection Agency, Risk Assessment Forum.

Valenti, T. W., Cherry, D. S., Neves, R. J., and Schmerfeld, J. (2005). Acute and chronic toxicity of mercury to early life stages of the Rainbow Mussel, Villosa iris (Bivalvia: Unionidae). Environ. Toxicol. Chem. 24, 1242-1246. doi: 10.1897/04-261R.1

van der Oost, R., Beyer, J., and Vermeulen, N. P. E. (2003). Fish bioaccumulation and biomarkers in environmental risk assessment: a review. Environ. Toxicol. Pharmacol. 13, 57-149. doi: 10.1016/S1382-6689(02)00126-6

Vidrine, M. F. (1996). North American Najadicola and Unionicola: Diagnosis and Distributions. Eunice: Gail Q. Vidrine Collectibles.

Wang, N., Ingersoll, C. G., Greer, I. E., Hardesty, D. K., Ivey, C. D., Kunz, J. L., et al. (2007b). Chronic toxicity testing of juvenile mussels with copper and ammonia. Environ. Toxicol. Chem. 26, 2048-2056. doi: 10.1897/06-524R.1

Wang, N., Ingersoll, C. G., Hardesty, D. K., Ivey, C. D., Kunz, J. L., May, T. W., et al. (2007a). Acute toxicity of copper, ammonia, and chlorine to glochidia and juvenile mussels. Environ. Toxicol. Chem. 26, 2036-2047. doi: 10.1897/06523R.1

Watters, G. T. (1999). More Anodonta woodiana. TUR 17, 18

Williams, J. D., Warren, M. L. Jr., Cummings, K. S., Harris, J. L., and Neves, R. J. (1993). Conservation status of freshwater mussels of the United States and Canada. Fisheries 18, 6-22.

Williams, J. W. (1890). A tumor in the fresh water mussel. J. Anat. Physiol. 24, 307. Woodhead, A. E. (1930). Life history studies on the trematode family Bucephalidae. No. II. Trans. Am. Microsc. Soc. 49, 1-17. doi: 10.2307/ 3222290

Woodhead, A. E. (1936). A study of the gasterostome cercariae of the Huron River. Trans Am. Microsc. Soc. 55, 465-476. doi: 10.2307/3222530

Yanovich, L. N., and Stadnichenko, A. P. (1997). Molluscs of the family Unionidae from the Central Polessye as intermediate hosts of the trematodes [in Russian with English summary]. Parazitologiya 31, 314-320.

Zhang, Z., Din, S., Xu, Y., and Wang, J. (1986). Studies on the mussel Hyriopsis cumingii plague. I. A new viral infectious disease [in Chinese with English summary]. Acta Microbiol. Sin. 26, 308-312.

Zhong, L., Xiao, T.-Y., Huang, J., Dai, L.-Y., and Liu, X.-Y. (2011). Histopathological examination of bivalve mussel Hyriopsis cumingii Lea artificially infected by virus. Acta Hydrobiol. Sin. 35, 666-671.

Conflict of Interest Statement: The authors declare that the research was conducted in the absence of any commercial or financial relationships that could be construed as a potential conflict of interest.

Copyright (c) 2016 Carella, Villari, Maio and De Vico. This is an open-access article distributed under the terms of the Creative Commons Attribution License (CC BY). The use, distribution or reproduction in other forums is permitted, provided the original author(s) or licensor are credited and that the original publication in this journal is cited, in accordance with accepted academic practice. No use, distribution or reproduction is permitted which does not comply with these terms. 